Volume 13

Issue 2 Rethinking Genocide, Mass Atrocities,

and Political Violence in Africa: New Directions,

Article 10

New Inquiries, and Global Perspectives

6-2019

\title{
The Fight for Language: An Exploration of the Nigerian State's Response to Protest Groups in Southeastern Nigeria
}

Chinonye A. Otuonye

CUNY, Graduate Center

Follow this and additional works at: https://digitalcommons.usf.edu/gsp

\section{Recommended Citation}

Otuonye, Chinonye A. (2019) "The Fight for Language: An Exploration of the Nigerian State's Response to Protest Groups in Southeastern Nigeria," Genocide Studies and Prevention: An International Journal: Vol.

13: Iss. 2: 106-115.

DOI:

https://doi.org/10.5038/1911-9933.13.2.1699

Available at: https://digitalcommons.usf.edu/gsp/vol13/iss2/10

This Articles is brought to you for free and open access by the Open Access Journals at Digital Commons @ University of South Florida. It has been accepted for inclusion in Genocide Studies and Prevention: An International Journal by an authorized editor of Digital Commons @ University of South Florida. For more information, please contact digitalcommons@usf.edu. 


\title{
The Fight for Language: An Exploration of the Nigerian State's Response to Protest Groups in Southeastern Nigeria
}

\author{
Chinonye Alma Otuonye \\ CUNY, Graduate Center \\ New York City, New York, USA
}

"Remember Biafra!" These are the chants that can be heard along the unpaved dirt roads of small Southeastern villages in Nigeria; a region abundantly prosperous in oil, but simultaneously underdeveloped. People are tired. They are tired of corrupt officials siphoning off their wealth to line their own pockets. People are tired of feeling forgotten and most of all people are tired of feeling voiceless. The contemporary call for Biafra is more than a vocal memorial to the past; it is a form of defense, for some, against what they perceive as a failing Nigerian state.

The Biafran-Nigerian War, predominately against Igbos, was largely unacknowledged by the Nigerian state, ended fifty years ago. While only lasting three years, it left a scar on a nation and on a people that has never fully been allowed to heal. It reinvigorated and politicized the significance of the Igbo identity within a people who understood the numerous barriers facing them due to perceived discriminatory practices and interactions. For a struggle grounded in the superficial construction of the Nigerian state and the forced cohesion of a multiplicity of ethnic groups, its end sought to ignore fundamental issues and instead forge a united path on a crumpled foundation. Fifty years later, a secessionist state that failed to survive has found its way out of the mangles of the past and into the forefront of a Nigerian present that is riddled with threats of terror and on the brink of an unquestionable future. The question of why Biafra has been revived has failed to register adequately with both local and federal Nigerian government officials. To ask that question assumes a prioritization of an understanding of the people's needs and a means of resolution towards a growing discontent. Rather, Nigerian forces have engineered a forceful push towards action to remedy what they understand as a threat to the nation.

The resurgence of pro-Biafra movements led by the likes of the Movement of Sovereign State of Biafra (MOSSOB) and the Indigenous Peoples of Biafra (IPOB) for more than a decade is a testament to the failed accountability of the Nigerian government to address the trauma of the Biafran war. The need to organize around a historical moment speaks to the presence of the past for a generation failed by Nigeria's democratization process. It speaks to cleavages within ethnic groups between the elite and non-elite and begs the question of whether historical memory is integral to the legitimization of violence. Nigeria's choice to ignore particular aspects of its history showcases its inadequacy to address the impact of state violence on its people. The labeling of and crackdown on these groups, as extremists that pose a threat to Nigerian security, disregards the core issues that allows these groups to exist. While an acknowledgement of the need's of Biafra vary between the present and past context, the underlying tension between the state and these secessionists groups remains the same: the protection of Nigerian security remains more important than the people who comprise the state.

This article aims to understand the ways in which language serves as a tool to invalidate the claims of citizens, which, in turn, fosters further tension between the state and minority groups rather than ameliorating them. I will focus on the ways in which the use of language, inclusive of "extremists" or "criminals" by the Nigerian government in labeling various protest groups in the Southeastern region, functions to assert control over the resource rich areas as well as public perception. This, thereafter, functions to justify violence towards these groups in the name of national security.

\section{Language and Power}

In the fight for a nationalistic identity, language plays a significant role in determining who controls and maintains power and how power can be used to exercise violence. The words chosen by political leaders have meaning that in many ways bypass that of everyday language, given the established power associated with these figures. The words we choose are purposeful in order to attain a goal. Whether we aim to persuade, command, flatter, or deceive, the words that help facilitate those ends, matter. With regards to the political arena, words have even larger significance. They have an influence on policy, resource distribution, development, and may have an implicit influence on security. As noted by Michaela Mocanu's article focusing on the use of political language, language 
in the political arena highlights a power hierarchy between those who speak and those forced to listen. As the speaker, there is a presumption of power in that one is afforded the right to speak thus relegating the listener to silence.

The relationship between word and power in this context becomes one of interdependence, thus having one means conquering the other. The powerful individual is not the only one who speaks, but the only one entitled to do it, the efficiency of a political discourse depending not only on the degree of transparency and intelligibility, but also on the status of the people mentioned. ${ }^{1}$

The speaker then can be understood as an authority figure whose words need to be adhered to and respected. The speaker is, therefore, the powerful part. As noted by Coates and Wade in their 2007 article on "Language and Violence,"

in democratic societies, political power is linked to the management of information and the power of rhetoric. The ability of any group to advance its interest hinges in part on the groups' ability to publicize its perspectives as more truthful or reasonable than others. ${ }^{2}$

Whose voice matters? Individuals outside the network of institutions in which credibility is given must fight for their voices to be heard beyond that of state institutions that have an inherent power in the lives of the masses. While Nigeria has seen itself move from a colonial to a military state to a democracy, it has been riddled with corruption and mismanagement. Its credibility and monopoly on influence through narrative is derived from an inherent belief among the populace in the capacity of the Nigerian state, as a moral authority that must be adhered to, but has rather been established as a result of who has power [wealth] and who has access to that power.

That is not to say that outside of institutions, individuals are voiceless and, therefore, powerless, but that institutions often times have the ability to "use language strategically in combination with physical or authority-based power to manipulate public appearances, promote their accounts in public discursive space, entrap victims, conceal violence, and avoid responsibility." ${ }^{3}$ The issue of language is, thus, also inextricably linked to how marginalized groups experience violence and how that violence is reduced.

Words serve a purpose and the discursive space is always used as a means through which to achieve a goal. With democratically elected political institutions which are supposed to speak for the people, protect the people, and fight for the people, there is an assumption the language of a country's political arena will be employed to ensure the safety of its people. There is an assumption that upon discontent, those in positions of power will pull back from language that is dismissive, alienating, and divisive. In the Nigerian context, however, we see time and time again the ways in which language is used as a tool to disregard the dialogic space and maintain power and control.

\section{A History of Biafra}

From its inception, Nigeria, as a nation-state, has been built around struggles for power and an underlying refusal towards the right of self-determination. As a product of colonialism, Nigeria found itself and its boundaries delineated by powers outside itself. Its people were refused a voice in its conception and forced under the directive of the British colonial powers. The land, its peoples, and its resources were used without consent. In this sense, Nigeria has seemingly known no other narrative than that of power, greed, and a disregard for the voices of its people. The story began with an assumption among colonial authorities of the impossibility of black self-rule. Following Hegelian modes of thought, the black mind could only be ruled by emotions, seemingly the most basic of human capabilities. This perceived lack of ability of black beings to evolve towards the rationality of their white counterparts necessitated the imposition of white bodies in a black space. The colonial administrators perceived it as their moral duty to civilize the barbarian.

${ }^{3}$ Ibid. 
The race for Africa saw the greed of European nations breaking apart and putting together the nation states of the African continent at their will. The amalgamation of the Nigerian state saw the combining of its Northern, Southwestern, and Southeastern sections into one unified whole. Nigeria was to be Britain's brain child. Upon its independence in 1960, it would showcase the ways in which diversity need not be an impediment to progress; Nigeria, despite its numerous ethnic and linguistic enclaves, was to transcend difference. However, independence brought with it an exacerbation of ethnic tensions. For peoples grounded in identification through ethnic understanding, British colonization served to complicate the issue of identity; an independent Nigerian state found itself imposing a Nigerian identity that its people had yet to fully integrate into their own understandings of self.

With colonial powers increasingly losing control over their territories, Nigeria's independence was thus an inevitability, or, as Achebe would later note, "Nigeria was given her freedom 'on a platter of gold."'4 Nigeria's independence then was more a result of changing times than an overwhelming struggle that ended British imperialism. This is not to negate the overwhelming actions taken by the peoples towards their political liberation, but to note the ways in which Nigerian independence functioned as a replacement of bodies in power. Freedom is always a struggle; it is a fight that necessitates a change of systems that function as oppressive to the overall progress of its people. If freedom is then not gained but "given on a plate" ${ }^{5}$ then it follows that the hegemonic powers that led to the creation of the Nigerian state and the power differentials that permeated Nigerian society remained. British officials were replaced by a Nigerian elite and the establishment of sectarian governments in the North and South, distinctly separated by three major political parties (the Northern People's Congress (NPC), the Action Group (AG), and the National Council of Nigerian and Cameroons (NCNC)) that functioned as safeguards for the three major ethnic groups (Hausa/Fulani, Yoruba, and Igbo), ${ }^{6}$ only perpetuated a nation's struggle towards unity and a real freedom from years of colonial oppression. As a newly independent nation, Nigeria's elite aimed to secure power through galvanizing its peoples through ethnic identity rather than a united national identity. In other words, "the weakness of the Nigerian political system, was that it never developed centripetal forces capable of counteracting the centrifugal ones." ${ }^{\prime 7}$ In this manner, Biafra was a war of inevitability; a foreseeable catastrophe.

Biafra's story begins in 1966, with a coup lead by Igbo military personnel. As noted, independence brought with it fragmentation and continued corruption that saw its answer in rising resentment. General Ironsi, an Igbo man, took power and fearing an Igbo government take-over, a countercoup occurred leading to the killings of a hundred Igbo officers and pogroms forcing millions of Igbos refugees back east. ${ }^{8}$ Biafra's existence was one that was not merely of its own wanting but a necessity for peoples fleeing to the east with stories of violence, death, and fear.

A sergeant ordered that all Easterners should raise up their hands...The sergeant asked us whether we could remember what happened on January 15th when the prime minister [Balewa] and the premier of the North [the Sardauna of Sokoto] lost their lives and the Ibos were all very happy. We said, "No, Sergeant." Paying no heed to that he asked us to give our names and addresses and send any messages we have for our people because we were going to die...They drove us five miles away to the Katsina road, brought us down and started shooting us. I felt my leg shattered and I fell down...I managed to crawl into the bush. ${ }^{9}$

In 1967, under the leadership of Cornel Chukwuemeka Odumegwu Ojukwu, Biafra declared itself a state. Using the language of liberation, it took the fear and need for survival of its people and used both to propel its cause, as a fight, towards black liberation and full decolonization. In a

\footnotetext{
${ }^{4}$ Chinua Achebe, There Was a Country: A personal History of Biafra (New York: Penguin Press, 2013), 52.

${ }^{5}$ Ibid.

${ }^{6}$ Arthur Aguwuncha Nwankwo and Samuel Udochukwu Ifejika, The Making of a Nation: Biafra (London: C. Hurst \& Company, 1969), 24-25; Chima J Korieh, "Biafra and the Discourse on the Igbo Genocide," Journal of Asian and African Studies 48, no. 6 (2013), 729.

${ }^{7}$ K.W.J. Post, “Is There a Case for Biafra?," International Affairs 44, no. 1 (1968), 30.

${ }^{8}$ Ibid.

${ }^{9}$ Ibid.
} 
moment of deep-seated fear, Ojukwu and his political officials were both able to use the language of state liberation, as a means to rally their constituents around the existence of Biafra, and belief in its preservation.

Though this present Biafran resurgence can be understood as a new struggle against Nigeria, the Nigerian forces' response is not unique to this present context. As the Nigerian administration maintains their goal remains national unity, the impetus of the original war, as vocalized by the Nigerian government, was that of unity. The necessity of General Gowon's tactics against the seceded Biafra nation was necessary under the premise that "Biafra wrecked the unity of a happy and harmonious state." ${ }^{10}$ As noted on the second anniversary of Biafra, Ojukwu's Ahiara Declaration set the tone for the ways in which Biafra would engage in their violent struggle as a result of what could be understood not only as a fight against the colonial construction of Nigerian rule but also the very present danger of the loss of a people. However, in thinking about the responses of both the 1967 Nigerian and Biafran governments, the recognition of oil that made Biafra an international struggle of sorts needs to be contextualized. British involvement in their former colony as a result of oil relations that they had established and maintained through their colonial administration highlights how Biafra was not simply a struggle for national unity as put forth by the 1967 Nigerian government.

Moreover, the political project of Biafra could well have broken up the oil and banking connections which helped to feed the British economy. In the crunch, the British looked to their Northern clients, whom they had had to persuade, time and again, to the idea of Nigerian unity, but who had always proved easy to manipulate, in part because the federation provided the North with access to the sea. Biafra, then, was an economic threat to England... ${ }^{11}$

Ojuwku, on the other hand, sought to ground Biafra in a history that superseded that of Nigeria and, therefore, any such requirement towards Nigerian unity. Fighting against a belief in Africa ahistoricity, Ojukwu's "Introducing the Republic of Biafra" sought to formulate an existence for Biafra grounded in the notion of it as a pre-colonial state that necessitated post-colonial recognition and devotion from its citizens.

It is a country inhabited from very early times by much of the same people as live there today. The people evolved a political system which for hundreds of years allowed each of the small component groups to manage its own affairs but all the same time to regain certain cultural and economic links that bound the country into a relatively peaceful homogeneous unit. $^{12}$

However, despite efforts to showcase the ingenuity of Biafrans to the eastern region in response to ongoing violence, Biafran political leaders understood their cause as embedded in black liberation struggles. As described in the Ahiara Declaration, they understood their proclamation for a state as a physical manifestation of anticolonial rhetoric. The Ahiara Declaration, released on the second anniversary of the establishment of the Biafran state, sought to revive a people that had regularly knew the trauma of starvation and death. It was a declaration proclaiming Biafra could not lose and Biafrans could and should not lose hope; after all Biafra needed them just as much as they needed Biafra. While Nigeria was engaging in its own propaganda strategies, Ojukwu's Ahiara declaration worked to retell the story of Biafra. It detailed the ways in which the Biafran cause was not simply a product of civil strife, but of a colonial rule that refused to extricate itself entirely.

But what do we find here in Negro Africa? The Federation of Nigeria is today as corrupt, as unprogressive and as oppressive and irreformable as the Ottoman Empire was in Eastern

\footnotetext{
${ }^{10}$ Frederick Forsyth, The Biafra Story (Barnsley: Pen \& Sword, 1977), 1.

${ }^{11}$ Stanley Diamond, “Who Killed Biafra," Dialectical Anthropology 31, no. 1/3 (2007), 353.

12 "Introducing the Republic of Biafra." Enugu: Government of the Republic of Biafra, May 30, 1967, accessed May 20, 2015, http://www.biafraland.com/Biafra history.htm.
} 
Europe over a century ago. And in contrast, the Nigerian Federation in the form it was constituted by the British cannot by any stretch of imagination be considered an African necessity. Yet we are being forced to sacrifice our very existence as a people to the integrity of that ramshackle creation that has no justification either in history or in the freely expressed wishes of the people. What other reason for this can there be than the fact that we are black? ${ }^{13}$

Assuming that Biafra functioned, as a cure for the black man towards a true independence, its survival, thus, became a necessity in order to provide a nation to a people allowed to rule themselves, protect themselves, promote themselves, and benefit themselves.

While the Ahiara Declaration was a reinvigoration of what Biafra stood for and why it was needed; the idea of what its existence would mean could not coexist with the reality of what its existence would cause. In 1970, Biafra became no more and with a motto "no victors, no vanquish" the east was reintegrated back into Nigeria. Biafran survivors, regardless of socio-economic status were stripped of their former lives. Their Biafran currency became null and void in Nigeria and some were given 20 pounds each regardless of their previous lives. Preferential treatment for government jobs was given to Yoruba and Hausa despite policies toward equal ethnic representation and equality. Such government mandated policies encouraged a silencing of the horrors of war, a disregard for the violence the war caused to the Igbo ethnic group, and perpetuated distrust among the ethnic groups the reintegration was aimed to bring back together.

\section{Government and Secessionist Groups}

Twenty years later, the silence lives on. Monuments and memorials remain largely unmade, a small yet significant aspect of the Nigerian story remains untaught in schools; the youth largely remain unaware of the intricacies of a war that left its mark on Nigeria as whole. Yet, despite a formalized silence by the government, there exists a renewed interest in Biafra. Groups like MASSOB and IPOB have popped up over the past two decades in response to what they believe to be as ongoing discrimination against the Eastern part of Nigeria. In a post-1999 Nigeria, a prevalent feeling of exclusion from Nigeria politics and the overall making of a new Nigeria remains; whether this is understood, as a result of governmental corruption or Igbo elite led corruption, for MASSOB and IPOB these have worked towards the detriment to Igbo progress. ${ }^{14}$

The idea of intergenerational trauma is one that cannot be ignored when thinking about the impact of the Biafran-Nigerian war on a new generation that is mostly calling for the same end. While Biafra remains largely in the rearview mirror of the older generation, a younger generation is bringing the wounds of the war back into public discourse..$^{15}$ With the inception of groups like MASSOB and IPOB, there is a clear divide within an older Biafran generation wishing never again to see the horrors of war and this new generation who view reclaiming Biafran sovereignty as a continued fight towards the right to self-rule they were denied. They are a generation who view the legacy of violence influencing their ability to adequately lead the lives owed to them.

However, prevailing sociopolitical and economic context and the emergence of new actors and forces in the Nigerian public space have served to strengthen manifestations of Igbo nationalism as it went through processes of change and renewal in the post-1970 era. ${ }^{16}$

\footnotetext{
${ }^{13}$ Chukwuemeka Odumegwu Ojukwu, The Ahiara Declaration: The Principles of the Biafran Revolution (Geneva: Markpress, 1969), 10.

${ }^{14}$ Daniel Smith, "Corruption Complaints, Inequality, and Ethnic Grievances in Post-Biafra Nigeria," Third World Quarterly 35, no. 5 (2014), 791.

${ }^{15}$ Daniel Smith in his work on corruption in the context of a post-Biafra Nigeria notes that outside of the Diasporic Igbos who have made prevalent the fight for Biafra, the local activists exist seemingly within the poor populations (particularly men) in urban spaces. These men are often Okada drivers who seem to symbolize the complexities, risks, and precarity of the Nigerian urban landscape. While the older generation are sympathetic towards pro-Biafra sentiments, they are aware that Biafra, at least for them, is a lost past.

${ }^{16}$ Godwin Onuoha, "Contesting the Space: The "New Biafra" and Ethno-Territorial Separatism in South-Eastern Nigeria," Nationalism and Ethnic Politics 17, no. 4 (December 2011), 408.
} 
They are a generation that invoke memories of the Abandoned Property Edict of 1969 that left their grandfathers/mothers' abandoning their homes and businesses during the war and without any compensation after the war's end. ${ }^{17}$ Despite their acknowledgement of corruption among Igbo elite, there is a steadfast belief that recompense is owed to them.

In an attempt to bring Biafra back into conversation, MASSOB and IPOB have been organized young Easterners, particularly Igbos living in the East, together to make their voices heard; they aim to unravel the sense of secrecy that has become normalized within Nigerian public and private life. ${ }^{18}$ However, in an attempt to silence the voices of the Eastern youth, the Nigerian government has engaged in dismissal tactics, which has allowed for the continuation of challenges to state legitimacy.

...different ethnic groups have continued to challenge the legitimacy of the Nigerian state, demanding a radical restructuring of the federal project in a manner that would accommodate their aspirations, interests, and desires. ${ }^{19}$

Nigeria has a rich history of struggle in response to what is understood as government repression against peoples. With movements such the Ogoni oil crisis, which sparked an international inquiry into the role and responsibility governments have over private companies, and the corporate responsibility of private companies in ensuring and maintaining human rights practices, Nigeria has struggled to find the necessary language that promotes engagement with rather than distrust of.

MASSOB started in 1999 under the relatively auspicious leadership of Chief Ralph Uwazuruike. With the inadequacies of post-civil war reconciliation, MASSOB represented a rebirth of a nationalist movement towards Igbo self-determination grounded in the idea of unequal treatment of Igbos socially and politically. ${ }^{20}$ With an understanding of the horrors and consequences of war and examples of methods towards nonviolence in the fight for freedom, MASSOB understands itself as a movement that follows the likes of India and the US. ${ }^{21}$ With flashbacks of the past, its aim is to remove violence from a freedom agenda. In a declaration concerning their demands, Uwazurike continually claimed to use the language of peace and dialogue in advancing his movement. For him, the overall aim is not to harm anyone, but the complete freedom of an Igbo people who have faced unrecognized trauma and discrimination.

MASSOB has therefore packaged about 25 stages for the actualization of the sovereignty of the new Biafra State through Non-violence and Non Exodus. By this process, no single life is expected to be lost in the realization of our new Biafra State. This method has worked in various countries, including India. The process admits of negotiations, dialogue and consultation. It also admits of non co-operative and passive resistance to oppressive and obnoxious laws of the authorities. Having hoisted the flag of our new Biafra today, we wish to declare our resolve to demand and pursue the realization of our sovereignty from the Federal Republic of Nigeria. We therefore call on the Federal Government of Nigeria to open up negotiation with MASSOB without any further delay for the realization of the new Biafra State. ${ }^{22}$

MASSOB, therefore, purports to represent a liberation struggle for the youth. With an Eastern region that is struggling with adequate access to education, structural improvements, and the lack of a fully representative federal government, MASSOB understands the reality of Biafra as a necessity to protect the Igbo youth of today and the future.

\footnotetext{
${ }^{17}$ Smith, Corruption Complaints, 792.

${ }^{18}$ Chimamanda Ngozi Adichie, “Hiding From Our Past," The New Yorker, May 1, 2014, accessed March 21, 2016, https:// www.newyorker.com/culture/culture-desk/hiding-from-our-past.

${ }^{19}$ Onuoha, Contesting the Space, 408.

${ }^{20}$ Ibid.

${ }^{21}$ Ralph Uwazuruike, “Declaration of Our Demand for a Sovereign State of New Biafra," Biafra Nation, May 21, 2000, accessed April 4, 2016, http://www.biafraland.com/Declaration Of Our Demand For A Sovereign State Of New Biafra. $\underline{\mathrm{htm}}$.

${ }^{22}$ Ibid.
} 
Yet, despite the use of nonviolent language and civil disobedience tactics, Biafra elicits a reference to a past that many believe should be long forgotten. With a public that does not fully understand the weight of the war on the present situation of Easterners and a Nigerian government with a tendency towards violence as a response, the narrative around a renewed Biafra has changed the story that the likes of MASSOB and IPOB have tried to create.

Simply put, for the Nigerian administration, Biafra is a tangible threat to national unity. A 2008 report by the US State Department on human rights abuses and practices in Nigeria noted the Nigerian government's response to groups they believed to be a threat. Such responses included the multiple arrests of MASSOB leader Ralph Uwazuruike, random arrests and detentions of those believed to be members of such groups. ${ }^{23}$ In other words, the Nigerian government has made efforts to systemically silence the voices they do not like. Those voices only serve to open up past wounds and possibly garner support for their cause. They have accused MASSOB members of violence and labeled them "common criminals" and "armed robbers." ${ }^{24}$ MASSOB has maintained it is a nonviolent organization whose members have been subjected to human rights abuses at the hands of Nigerian forces. ${ }^{25}$

MASSOB is not alone, however, in being on the receiving end of maltreatment. The Indigenous People of Biafra (IPOB), led by Nnamdi Kanu, has increasingly become the face of pro-Biafra movements over the past several years. As with its predecessor in MASSOB that "drew from a collective sense of Igbo heroics and achievements in the past, and a perception of deprivation, marginalization, and injustice against Igbo in the Nigerian state," IPOB and Kanu have propagated imagery to illicit a strong sense of Igbo identity. ${ }^{26}$ Their website states that IPOB are the "original inhabitants and owners of the Lands and Communities of Biafra and Biafraland spanning centuries of tradition and historical ancient cultural ties." ${ }^{27}$ This serves as a reference to the Ahiara Declaration that outlined the existence of Biafra long before colonial rule.

However, despite its appeals to an older time, IPOB has yet to receive full support from the Eastern community. Though they understand them and their Eastern brothers and sisters to be "slaves" in a government run by the Hausa-Fulani, ${ }^{28}$ their inability to have the backing of the majority of Easterners (both young and old) and outside international support towards their causes has provided space for the Nigerian government to shape them as a violent organization terrorizing the Eastern region and disregarding the values of a democratic society. In an effort to neutralize such a threat, the violence used by Nigerian forces is justified through the use of rhetoric likening groups such as MASSOB and IPOB to a threat against Nigeria and its peoples.

IPOB campaigners say they are committed to peaceful protests, but their demonstrations prompted the military to issue an "unequivocal warning" that efforts to bring about the "dismemberment of the country" would be crushed. ${ }^{29}$

The campaign against dissent waged by the Nigerian security forces has seen them justify the deaths of hundreds as this movement towards self-rule continues. The use of violent language has given way to the use of violent action. A June 2016 Amnesty International news report found "that between 29-30 May 2016, the Nigerian military opened fire on members of the Indigenous people

\footnotetext{
${ }^{23}$ United States Department of State. “Nigeria." Country Reports on Human Rights Practices for 2008, February 25, 2009, accessed April 4, 2016, https://www.state.gov/j/drl/rls/hrrpt/2008/af/119018.htm.

${ }^{24}$ Senan Murray, "Reopening Nigeria's Civil War Wounds," BBC, May 30, 2007, accessed March 22, 2016, http://news.bbc. co.uk/2/hi/africa/6657259.stm.

25 "Nigeria: Government Cracks Down on Biafra Separatist Resurgence," Integrated Regional Information Networks (IRIN), September 2006, accessed April 15, 2016, http://www.irinnews.org/report/53971/nigeria-government-cracks-downbiafra-secessionist-movement.

${ }^{26}$ Onuoha, Contesting the Space, 412.

${ }^{27}$ Indigenous People of Biafra (IPOB), "About Us," ipob.org (blog), accessed March 22, 2016, http://www.ipob.org/p/blogpage $18 . \mathrm{html}$.

${ }^{28}$ Ibid.

${ }^{29}$ Alex Akwagyiram, “Decades after Nigeria's War, New Biafra Movement Grows," Reuters, November 30, 2015, accessed April 3, 2016, https://www.reuters.com/article/us-nigeria-politics-biafra-insight-idUSKBN0TJ1WM20151130.
} 
of Biafra (IPOB), supporters and bystanders at three locations in [Onitsha, Anambra state]." ${ }^{30}$ To Nigerian security, however, the force and deaths were justified in that they were result of selfdefense. ${ }^{31}$ Though they have claimed less people were killed and that members of IPOB murdered two policemen, Amnesty international could find no proof of such claims. ${ }^{32}$ In Amnesty's annual report on Nigeria, it found that "on 9 February, soldiers and police officers shot at about 200 IPOB members who had gathered for a prayer meeting at the National High School in Aba, in Abia state." ${ }^{33}$ With the $50^{\text {th }}$ anniversary of the Nigerian-Biafran War coming up, there was mounting worry that Nigerian security forces would engage in the same behavior that lead over 60 people being gun down last year. In response, Osai Ojigho, Director of Amnesty International Nigeria, called on Nigerian security forces "to conduct themselves in a manner that [would] ensure public order without resorting to force." ${ }^{34}$ Though little is done in the name of justice for those killed by Nigerian forces, Nigeria has now thrust itself further into the international spotlight with its treatment of dissenting voices.

Following this logic and in the name of protecting the unity of Nigeria, separatist groups need to be done away with. However, the voices of its members (the most vulnerable) fail to reach the ears of those in power. Groups like MASSOB and IPOB have been able to live on despite continued governmental threats and repression because they reach an audience who already felt excluded. With growing unemployment, numerous college graduates, and an Eastern region that has yet to be adequately developed, young Easterners are the targets of a pro-Biafra message that promises better days ahead. "Of course I'm in support of Biafra," said a 28-year-old wholesale food trade, Uchenna Ede. "If we are freed, the eastern part of Nigeria would have a huge turnaround." 35

Voices like Uchenna are the ones most hurt. Living within the current moment and in such precarious times, voices like Uchenna represent the worries of a younger generation who feel abandoned. MASSOB and IPOB have capitalized on these feelings of discontent and have worked to mobilize around history and memory. However, while this cry for Biafra calls for the creation of an Igbo majority state, this feeling is not necessarily shared. The lack of unity on the topic of Biafra among Igbo while important should not dismiss other concerns that pro-Biafra sentiments bring up. Biafra, while understood as an Igbo struggle in particular, is an area that encompasses a multiplicity of minority identities. However, this connotation of Biafra with Igboness provides little room for other claims of sovereignty within the area. Biafra is, thus, created as a nation using Igbo nationalism that hinges upon Igbo identity formation. The nationalism functions to overshadow the ways in which minority groups within the East engage in their own identity formations. ${ }^{36}$ Originally Biafra channeled notions of Pan-Africanism and was, as such, meant to be an inclusive state that recognized the multiplicity of identities within it. However, newer thinking on the issue can be understood to be predominately Igbo led as well as centralized under Igbo emotive ethnic understandings of self. This nexus between minority rights and the implications of creating of Biafran state needs to be considered seriously, however, Nigeria's response is not that of protection mechanisms for minorities against Igbo hegemonic dominance, but rather one that seemingly functions to maintain Nigerian control.

The forces being used against young and frustrated Easterners only further perpetuates the idea that Biafra's secession is a real necessity to the Eastern region's ability to flourish. The Biafra of

\footnotetext{
30 "Nigeria: Killing of Unarmed Pro-Biafra supporters by military must be urgently investigated," Amnesty International, June 10, 2016, accessed July 15, 2017, https://www.amnesty.org/en/latest/news/2016/06/nigeria-killing-of-unarmedpro-biafra-supporters-by-military-must-be-urgently-investigated/.

${ }^{31}$ Ike Okonta, "Biafra of the mind: MASSOB and the mobilization of history," Journal of Genocide Research 16, no. 2/3 (2014).

${ }^{32}$ Ibid.

${ }^{33}$ Amnesty International, Amnesty International Report 2016/2017-Nigeria, February 22, 2017, accessed April 18, 2018, https:// www.amnesty.org/en/countries/africa/nigeria/report-nigeria/. DOI: 10.1111/j.1467-825X.2018.08279.x

34 “Nigeria: Security Forces Must Avoid Repression of Biafra Day Protest," Amnesty International, May 30, 2017, accessed July 21, 2017, https://www.amnesty.org/en/latest/news/2017/05/nigeria-security-forces-must-avoid-repression-ofbiafra-day-protests/.

${ }^{35}$ Alex Akwagyiram, “Decades after Nigeria's War, New Biafra Movement Grows,” Reuters, November 30, 2015, accessed April 3, 2016, https://www.reuters.com/article/us-nigeria-politics-biafra-insight-idUSKBN0TJ1WM20151130.

${ }^{36}$ Smith, Corruption Complaints, 794.
} 
old was a stance against the power of the colonial experience in the functioning of African politics. Biafra is not simply a threat to Nigerian existence, but to the hegemonic powers that brought Nigeria about to begin with. Fifty years later, this call for Biafra is a recycled stance towards freedom etched with the bitterness and disappointment of youth that have yet to see how their lives have been made better by Nigerian unification; of youth who are aware of the violence their parents and grandparents faced, and who feel as though justice has never been delivered.

On a continent that had its fate decided for it rather than by it, its peoples are still navigating what is means to have emerged from within a conception of the state in which they had zero voice. The cry for Biafra and the response by Nigerian forces highlight a tension between a need to remain and a need to reexamine. The inability to see the violence perpetrated against a people some fifty years past and the implications of the violence to the power and strength of their voice further undermines a group that already feels systematically oppressed and neglected. Rather than engage in dialogue towards understanding, the Nigerian government has waived a dismissive hand at their claims and only further proved their point...that they live within a nation that has no regard for their fears and wounds. Instead, Nigerian forces continually seek to alter the narrative of the Biafran story in the hopes that if they can change the story they can change people's minds. They have used a language of security as a means of justifying violence and in the process shown how disposable they view their own people.

\section{Bibliography}

Achebe, Chinua. There Was a Country: A Personal History of Biafra. New York: Penguin Press, 2013.

Adichie, Chimamanda Ngozi. "Hiding From Our Past." The New Yorker, May 1, 2014. Accessed March 21, 2016. https://www.newyorker.com/culture/culture-desk/hiding-from-our-past.

Akwagyiram, Alex. "Decades after Nigeria's War, New Biafra Movement Grows," Reuters, November 30, 2015. Accessed April 3, 2016. https://www.reuters.com/article/us-nigeriapolitics-biafra-insight-idUSKBN0TJ1WM20151130.

Amnesty International. Amnesty International Report 2016/2017-Nigeria, February 22, 2017. Accessed April 18, 2018. https://www.amnesty.org/en/countries/africa/nigeria/report-nigeria/.

Coates, Linda and Allan Wade. "Language and Violence: Analysis of Four Discursive Operations." Journal of Family Violence 22, no. 7 (2007), 511-522. DOI: 10.1007/s10896-007-9082-2

Diamond, Stanley. “Who Killed Biafra." Dialectical Anthropology 31, no. 1/3 (2007), 339-362. DOI: 10.1007/s10624-007-9014-9

Forsyth, Frederick. The Biafra Story. Barnsley: Pen \& Sword, 1977.

Indigenous People of Biafra. "About Us." Ipob.org (blog). Accessed March 22, 2016. http://www. ipob.org/p/blog-page 18.html.

"Introducing the Republic of Biafra." Enugu: Government of the Republic of Biafra, May 30, 1967. Accessed May 20, 2015. http://www.biafraland.com/Biafra\%20history.htm.

Korieh, Chima J. "Biafra and the discourse on the Igbo Genocide." Journal of Asian and African Studies 48, no. 6 (2013), 727-740. DOI: 10.1177/0021909613506455

Mocanu, Michaela. "The Identity of the Political Language, Compared to Other Types of Language." International Letters of Social and Humanistic Sciences, 45 (2015), 35-46. DOI: 10.18052/www. scipress.com/ilshs. 45.35

. "Verbal Language- A Sign of Political Power in the Political Arena." Philologica Jassyensia 7, no. 2 (2011), 335-342.

Morrison, Jago. "Imagined Biafras: Fabricating Nation in Nigerian Civil War Writing." Ariel, 36, no. $1 / 2$ (2005), 5-26.

Murray, Senan. "Reopening Nigeria's Civil War Wounds." BBC, May 30, 2007. Accessed March 22, 2016. http://news.bbc.co.uk/2/hi/africa/6657259.stm.

"Nigeria: Killing of Unarmed Pro-Biafra Supporters by Military Must be Urgently Investigated," Amnesty International, June 10, 2016. Accessed July 15, 2017. https://www.amnesty.org/en/ latest/news/2016/06/nigeria-killing-of-unarmed-pro-biafra-supporters-by-military-mustbe-urgently-investigated/. 
"Nigeria: Government Cracks Down on Biafra Separatist Resurgence," Integrated Regional Information Networks (IRIN), September 2006. Accessed April 15, 2016. http://www.irinnews. org/report/53971/nigeria-government-cracks-down-biafra-secessionist-movement.

"Nigeria: Security Forces Must Avoid Repression of Biafra Day Protest," Amnesty International, May 30, 2017. Accessed July 21, 2017. https://www.amnesty.org/en/latest/news/2017/05/ nigeria-security-forces-must-avoid-repression-of-biafra-day-protests/.

Nwankwo, Arthur Aguwuncha and Samuel Udochukwu Ifejika. The Making of a Nation: Biafra. London: C. Hurst \& Company, 1969.

Ojukwu, Chukwuemeka Odumegwu. The Ahiara declaration: The Principles of the Biafran Revolution. Geneva: Markpress, 1969.

Okonta, Ike. "Biafra of the Mind: MASSOB and the Mobilization of History." Journal of Genocide Research 16, no. 2/3 (2014), 355-378. DOI: 10.1080/14623528.2014.936710

Onuoha, Godwin. "Contesting the Space: The 'New Biafra' and Ethno-Territorial Separatism in South -Eastern Nigeria." Nationalism and Ethnic Politics 17, no. 4 (2011), 402-422. DOI: $10.1080 / 13537113.2011 .622646$

Post, K.W.J. “Is there a case for Biafra?" International Affairs 44, no. (1968), 26-39.

Smith, Daniel. "Corruption Complaints, Inequality, and Ethnic Grievances in Post-Biafra Nigeria." Third World Quarterly 35, no. 5 (2014), 787-802. DOI: $10.1080 / 01436597.2014 .921430$

United States Department of State. "Nigeria." Country Reports on Human Rights Practices for 2008. February 25, 2009. Accessed April 4, 2016. https://www.state.gov/j/drl/rls/hrrpt/2008/ af/119018.htm.

Uwazuruike, Ralph. "Declaration of Our Demand for a Sovereign State of New Biafra." May 21, 2000. Accessed April 4, 2016. http://www.biafraland.com/Declaration $\% 200 f \% 200 u r \% 20$ Demand \%20For\%20A\%20Sovereign\%20State\%200f\%20New\%20Biafra.htm. 